\title{
Japanese companies bring halt to imports of uranium
}

Tokyo

IN response to international and government pressure, several of Japan's giant electric power companies decided last week to halt imports of uranium from South Africa and Namibia. The two countries are major suppliers of fuel for Japan's huge nuclear power industry. But Tokyo Electric Power Company, the world's largest electric utility, says it will continue imports from Rio Tinto Zinc (RTZ), a British mining company which derives much of its uranium from Namibia.

At a time when many Western countries are clamping down on trade with South Africa in protest against apartheid, Japan last year found itself in the embarrassing position of being South Africa's number one trading partner with a two-way flow in trade of over $\$ 4,000$ million. Trade in dollar terms is expected to be even higher this year and Japan has come under pressure from its allies to impose stricter sanctions.

Japan's Ministry of International Trade and Industry and the Ministry of Foreign Affairs have been trying for two years to persuade electric power companies to end South African uranium imports. The

Sech ingratitude, efter we
made them honorary Whites!

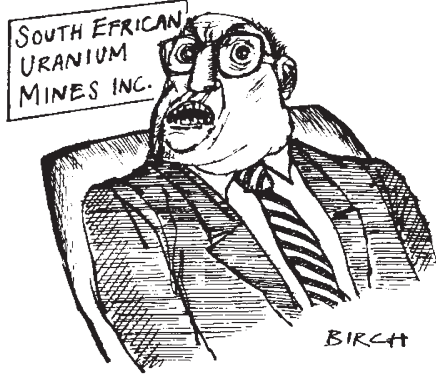

United States banned imports of uranium from South Africa in 1986. This year, the United Nations issued a decree prohibiting imports from Namibia, which is governed by South Africa in defiance of a United Nations resolution.

The big electric power companies in Japan have argued that they cannot cancel long-term contracts. But they have now decided they will not renew them. On 1 November, Tohoku, Kansai, Kyushu, Chubu and Chugoku electric power companies jointly announced that contracts with South Africa and RTZ will be allowed to lapse between 1989 and 1995 .

As at March 1987, about 11 per cent of Japan's uranium imports, or 22,000 short tons, was derived from South Africa. But virtually none of the ore was imported directly. Japan has only very limited facili- ties for enrichment and most of the uranium was purchased as uranium hexafluoride and shipped to France and the United States for enrichment - despite an import ban on South African uranium ore, the United States continues to enrich partially processed uranium of South African origin.

Japan also obtains considerable amounts of uranium from RTZ, whose uranium mine in Namibia is one of the largest open-cast operations in the world, according to John Skinner, press officer for RTZ in London. For example, by 1989 ,
Chubu Electric Power Company will have imported nearly 4,000 short tons from RTZ under a 12-year contract. But RTZ also operates a large uranium mine in Canada and precise figures for Namibian imports are not available.

Despite uncertainty over the origin of RTZ's uranium, Tokyo Electric Power Company, which operates 11 out of Japan's 36 nuclear power plants, says it will continue imports from RTZ. A company spokesman says RTZ has provided a written guarantee that none of the uranium supplied will be of Namibian origin. But Skinner says he can "neither confirm nor deny" the existence of such an agreement. RTZ, as a matter of policy, does not discuss its commercial contracts, he says.

David Swinbanks

\section{Protests in Japan about trade in tropical forest timber}

Tokyo

"STOP Japan's chainsaw massacre in Sarawak". This sign greeted passers-by in downtown Tokyo as environmental groups launched a one-day campaign on 31 October to protest against Japan's involvement in the tropical timber trade.

Japan imports nearly half of the world's tropical timber, making it by far the biggest consumer. But most Japanese are totally unaware of this fact according to Yoichi Kuroda of the Japan Tropical Forest Action Network (JATAN). The bulk of the timber comes from Sarawak. Malaysia's eastern state, where logging has destroyed more than 30 per cent of the total forest area.

In Tokyo environmentalists submitted a petition and letter calling for a halt to tropical timber imports to Prime Minister Noboru Takeshita, the Ministry of Agriculture, Forestry and Fisheries, the Ministry of Foreign Affairs and companies involved in the import of tropical timber. including $\mathrm{C}$. Itoh and Nissho Iwai.

Coordinated protests took place in more than twenty countries. Demonstrations were staged outside Japanese embassies and Japanese trading companies. The protests were intended to coincide with the day when 42 Kayan tribespeople from Sarawak were to go on trial in a Malaysian court for blockading a timber road to protest logging activities. The trial has now been postponed until April.

Outside Malaysia, Japanese companies are involved in logging operations throughout South-East Asia. Marubeni Corporation is soon to begin imports of wood chips from a logging operation in western (Indonesian) Papua New Guinea that threatens one of the largest primary mangrove swamps in east Asia.

The mangrove in Bintuni Bay has been provisionally designated as a nature reserve by the Indonesian government. But surveys of the reserve have yet to be carried out, and in 1983 a local company, P.T. Bintuni Murai Wood Industries, was given a logging concession of 137,000 hectares, about a third of which overlaps with the reserve.

Indonesian environmental regulations require preservation of a coastal strip of mangrove and isolated 'mother trees' in logged areas to give the mangrove a chance to regenerate. Kuroda says he recently asked the director of Marubeni's wood chip division if the Indonesian regulations would be followed: the Marubeni official said that the logging plan is the responsibility of the local company. Marubeni just imports the chips.

David Swinbanks

\section{Dial-a-scientist links three continents Sydney}

Australians should soon be able make use of a new dial-a-scientist service. Aimed primarily at journalists, parliamentarians and teachers, the service will provide access to experts in all realms of science and help to arrange laboratory visits for schoolchildren. The service is intended to be a catalyst towards a global network and will begin by making links with the Scientist's Institute for Public Information in New York, the Ciba Foundation Media Resource Survey in London and the Science Information Sources Organization in Toronto.

The Australian Academy of Science has raised $A \$ 50,000$ for the service. An expected government grant for $\mathbf{A} \$ 313,000$ should allow a start in 1989.

Charles Morgan 